\title{
Intergroup Threat and Affective Polarization in a Multi-Party System
}

\author{
Emma A. Renström ${ }^{1}$, Hanna Bäck ${ }^{2}$, Royce Carroll ${ }^{3}$ \\ [1] Department of Psychology, University of Kristianstad, Kristianstad, Sweden. [2] Department of Political Science, Lund University, Lund, Sweden. \\ [3] Department of Government, University of Essex, Colchester, United Kingdom.
}

Journal of Social and Political Psychology, 2021, Vol. 9(2), 553-576, https://doi.org/10.5964/jspp.7539

Received: 2020-04-27 • Accepted: 2021-07-15 • Published (VoR): 2021-11-18

Handling Editor: Jasper Van Assche, Ghent University, Ghent, Belgium

Corresponding Author: Emma A. Renström, Department of Psychology, University of Kristianstad, Elmetorpsvägen 15, 291 39, Kristianstad, Sweden. E-mail: Emma.Renstrom@hkr.se

\begin{abstract}
What explains affective polarization among voters and societal groups? Much of the existing literature focusing on mass political polarization in modern democracies originates in the US, where studies have shown that, while ideological separation has grown, political conflict increasingly reflects social identity divisions rather than policy disagreements, resulting in affective polarization. We focus on explaining such polarization in a multi-party context. Drawing on social identity theory and intergroup threat theory, we hypothesize that individuals who perceive an intergroup threat show stronger intergroup differentiation and increased affective polarization. We analyze the influence of perceived threat on affective polarization drawing on two large-scale representative surveys in Sweden ( $\mathrm{N}=1429$ and 1343). We show that individual-level affective polarization is related to perceived intergroup threats among the voters in both studies, measuring affective polarization using social distance, negative trait attribution, and party like-dislike ratings.
\end{abstract}

\section{Keywords}

affective polarization, intergroup threat, social identity, multi-party system, survey data

How does perceived threat influence the level of conflict between various groups in society and mass polarization among voters? Much of the existing literature focusing on mass political polarization in modern democracies originates in studies of the US (Iyengar et al., 2019). Such studies show that Democrats and Republicans both say that the other party's members possess a range of negative traits to a larger degree than the members of their own party, known as "affective" polarization (Iyengar, Lelkes, Levendusky, Malhotra, \& Westwood, 2019; Iyengar \& Westwood, 2015). Studies of US voters have noted that, while ideological separation has grown, the conflicts between partisan groups increasingly reflect social identity divisions rather than ideological or policy disagreements (Mason 2013, 2018).

Because affective polarization is based on group identities, it is grounded in the forces identified by social identity theory (SIT, Tajfel \& Turner, 1979). Individuals, according to SIT, form an emotional and psychological attachment to social groups, which becomes an important part of how they define themselves. These individuals strive to be members of valued social groups, but the extent to which an individual identifies with a group varies (Tajfel \& Turner, 1986). In the social-psychological literature, threats posed by other groups strengthen intergroup emotions - positive toward the own group and negative toward other groups (Mackie et al., 2000) - and lead to increased intergroup distancing (Stephan et al., 2009), which is at the heart of affective polarization. Drawing on this literature, we argue that individuals who perceive a higher degree of intergroup threat will exhibit higher levels of affective polarization.

Several scholars have called for comparative research on affective polarization outside the US context (Gidron et al., 2019; Iyengar et al., 2019). The present paper contributes to a growing research literature in this area in multi-party 
contexts (e.g. Knudsen, 2021; Gidron et al., 2020; Harteveld, 2021; Wagner 2021) using data from Sweden, a multi-party system with a relatively high degree of affective polarization compared to other Western European countries (Reiljan, 2020). In addition, we contribute to the growing literature on affective polarization by analyzing why some individuals are more biased than others when evaluating their in- and outgroups, focusing specifically on the role of intergroup threat.

\section{Theory and Hypotheses}

\section{Affective Polarization and the Role of Social Identities}

Affective polarization is based on group identities, which can be understood in terms of social identity theory (e.g. Tajfel \& Turner, 1979, 1986). As mentioned, according to SIT, the social groups an individual belong to become a significant part of their self-definition through the formation of both emotional and psychological attachment to the groups. Because group belongingness is emotionally important (Tajfel, 1978), individuals strive to become or stay members of valued social groups but vary in the extent of their identification with such groups (Tajfel \& Turner, 1986).

While classic social psychological research shows that simple arbitrary group boundaries are sufficient for eliciting intergroup differentiation, social groups are central to an individual's self-definition, thereby influencing emotions and behavior. The stronger an individual identifies with a social group, the more important it is for them to defend this identity and the more the individual is prone to invest time, money, and energy to remain part of the group, defend its values, and secure its future. In essence, the group becomes an extension of their own identity and must therefore be protected in the same way, such as when there are external threats to the group.

This emotional attachment lays the foundation for affective polarization and distinguishes it from ideological polarization. The categorization of individuals into socially constructed categories based on attitudes or party memberships facilitates general inferences about the members of these categories, even if the conclusions are not correct (Iyengar et al., 2019).

Previous Research on Individual-Level Determinants of Affective Polarization - Much of the existing literature trying to identify determinants of affective polarization has focused on system-level (Boxell et al., 2020; Lauka et al., 2018; Reiljan, 2020) or party-level correlates (Gidron et al., 2019), although some recent studies have focused on evaluating individual-level determinants of affective polarization (Harteveld, 2021; Reiljan \& Ryan, 2021; Wagner 2021). Previous research has identified two main individual-level drivers of affective polarization. First, because political group attachments may function as a social identity, strengthening group identification increases intergroup differentiation, which manifests as affective polarization between supporters of parties (Mason, 2015; Iyengar et al., 2012; Reiljan \& Ryan, 2021; Webster \& Abramowitz, 2017). Second, previous research has shown that if individual political attitudes are ideologically more extreme, individuals become more affectively polarized (Harteveld, 2021; Lelkes, 2021; Rogowski \& Sutherland, 2016; Webster \& Abramowitz, 2017). Both ideas have received some empirical support in the US and some multi-party systems (Harteveld, 2021; Reiljan \& Ryan, 2021; Renström, Bäck, \& Schmeisser, 2020; Webster \& Abramowitz, 2017). The present paper contributes to this ongoing debate by focusing on how affective polarization between partisans is related to the interaction between political group identity and individual-level sensitivity to concerns about societal challenges.

Threat Perceptions and Affective Polarization - Identifying with a certain group creates positive emotions towards the group and often negative emotions towards other groups (Haslam et al., 2010). This is the basic foundation of social identity theory (Tajfel \& Turner, 1986). In the face of threats against the ingroup, social identification may strengthen and, as a consequence, intergroup differentiation (Riek, Mania, \& Gaertner, 2006). The mere creation of groups almost inevitably creates intergroup tension, which is amplified when one group perceives that another group is in a position to challenge their values and resources. This is the central notion of intergroup threat theory (Stephan et al., 2009; Stephan et al., 2015), which we draw on here. An extensive literature has noted the importance of threat perceptions in influencing political behavior (e.g., Merolla et al., 2007; Merolla \& Zechmeister, 2009; Miller \& Krosnick, 2004). Threats 
posed by other social groups strengthen intergroup differentiation - ingroup liking and outgroup disliking (Mackie et al., 2000) - which is at the heart of affective polarization.

However, what constitutes a threat is based on an individual's perception and evaluation of a situation or target. Individuals vary in the extent to which they perceive something as a threat, and in earlier research, individual-level features such as Right-wing Authoritarianism have been linked to the perception of immigrants as threatening and increased anti-immigrant sentiments (e.g., Lavine, Lodge, \& Freitas, 2005; Peresman, Carroll, \& Bäck, 2021). Here, we argue that ideological identification determines who is likely to perceive a particular societal challenge as threatening and should therefore influence when affective polarization is likely to occur. For instance, an increase in immigration may be seen as a matter of concern regardless of whether you identify as left or right, but is more likely to be perceived as a threat by those who identify with the cultural right.

Recent decades have seen a rapid increase in globalization, with increased movement across countries where national boundaries have become more permeable. Moreover, the influx of refugees due to conflicts has sometimes contributed to immigration tensions. Globalization and mass immigration may be perceived as threats by the host countries' citizens (Hainmueller \& Hopkins, 2014). Right-wing populist parties and candidates have stressed such threats, leading to more polarized electorates. For instance, immigrants may be perceived as "taking native citizens' jobs" or "exploiting welfare systems" or as imposing on citizens' way of life via their religions or cultures. As part of this ideological shift, party competition in the US has become more aligned with the identities surrounding 'authoritarian values' (MacWilliams, 2016), which is seen in attitudes on immigrants, race, security, and nationalism. Political preferences are increasingly connected to perceived threats and, at the mass level, partisan divisions are increasingly social-identity-based - suggesting an increased affective polarization in the electorate (Iyengar et al., 2012).

Although not as closely aligned with party attachments as in the US two-party system, political identity in European multi-party democracies is also connected to these broad ideological attachments. This is most visible in the growth of populist right-wing parties capitalizing on reactions to globalization and traditional parties changing pre-emptively and in response to such parties, which has led to polarization in the political systems of Europe by enhancing the role of social identity as a basis for political support. As a result, identification as "left" and "right" increasingly captures these social identities rather than only policy differences. 'Expressive social identity' (Huddy et al., 2015) focuses on the idea that 'maintenance of group distinctiveness is an active process, especially when a group's position or status is threatened.' A core mechanism in making social identity politically salient is the activation of attitudes on issues pertaining to group threats. In the context of reactions to globalization, these manifest chiefly as anti-immigrant attitudes.

Threats may come in different forms and, importantly, may appeal differentially to different individuals. As previous literature has described, a major aspect of the rising right-wing populist, "thin" ideology (Mudde, 2007; Stanley, 2008) is that immigration is framed as a threat, one that within the party system, is associated with culturally left parties seen as more tolerant of immigrants. Meanwhile, parties focused on skepticism towards immigrants and other minority groups can themselves be perceived as a threat to those more aligned with left-wing ideological ideas and values - that is, the left is likely to feel threatened by the growing influence of the cultural right. In line with intergroup threat theory (Stephan et al., 2009), the populist right is in a position to threaten the values of those that identify with the left, which ultimately should influence affective polarization.

We argue that intergroup threat increases affective polarization, but what societal challenges are perceived as threats is dependent upon an individual's ideological leaning because individuals identifying as left-wing are likely to perceive different challenges as threatening than individuals identifying as right-wing. Our overarching expectation is that perceived intergroup threat increases affective polarization. More specifically, we expect that individuals who identify with right-wing values and who are more concerned with immigration will show increased affective polarization. Meanwhile, individuals who identify with left-wing values and who are more concerned with challenges to democracy (e.g., extremism) will show increased affective polarization. Hence, we expect an interaction between types of societal challenges and ideological identification in predicting affective polarization. 


\section{Method and Data}

\section{Overarching Research Design}

The analyses performed here are based on survey data collected in Sweden at two points in time - in 2013 and in 2019. To give a brief introduction to the case, the Swedish multi-party system, resulting from a proportional electoral system, consists of eight parties in the parliament: the socialist Left Party, the Social Democrats, Greens, Liberals, Centre Party (former Agrarian Party), the conservative Moderate Party, the Christian Democrats, and the Sweden Democrats. The Sweden Democrats is a populist right-wing party that entered the parliament in 2010 and has since grown to become the third-largest party in the most recent election (in 2018). Swedish politics has traditionally been strongly unidimensional, with a dominance of the left-right/economic dimension. Similar to many other countries, right-wing populism has grown as globalization issues have become part of the political agenda. Some evidence suggests the Swedish party system may be growing in polarization on these issues, with the Sweden Democrats being placed far away from the other parties (Lindvall et al., 2017, p. 75).

The analyses in this paper are based on representative data drawing on the Swedish national SOM (Society, Opinion and Media) survey. We base our analyses on two data collections, one in 2013 and one in 2019, where we added specific questions measuring affective polarization in the 2019 wave. The SOM institute is hosted by the University of Gothenburg and has collected surveys targeting the general public since $1986 .{ }^{1}$ The survey usually targets about 10,000 participants, but not all questions are posed to all participants. In both samples reported here, the number of participants was about 1,500 .

\section{Measuring Affective Polarization}

Our main dependent variable is affective polarization, which has been differentially measured in studies of different countries (Boxell et al., 2020). Outside the US context, feeling thermometers or like-dislike scales have been the most common approach (Boxell et al., 2020; Druckman \& Levendusky, 2019; Lelkes \& Westwood, 2017; Wagner 2021). Another approach, which has mainly been used in the US context, is to ask participants to rate the parties or their supporters on different traits such as intelligence, honesty, open-mindedness, selfishness, and hypocrisy (Druckman \& Levendusky, 2019; Garrett et al., 2014; Iyengar et al., 2012). Yet another way to measure affective polarization is to use what is known as a social distancing measure. Such measures are based on questions gauging how comfortable participants are in having close interpersonal relations with supporters of another party, such as if their children would marry someone from the other party (Iyengar et al., 2012; Iyengar et al., 2019). The present paper contributes to a growing research literature in this area in multi-party contexts (e.g. Knudsen, 2021; Levendusky \& Malhotra, 2016).

In this article, we perform our analyses using several different measures of affective polarization. In the data from 2013, we analyze a like-dislike scale, and in the 2019 data, we use supporter trait ratings and a social distancing variable to measure affective polarization. Importantly, these survey data allow us to apply the latter type of affective polarization measures to Sweden for the first time, as previous works have relied only on like-dislike scales for in- and outgroup parties (Boxell et al., 2020; Reiljan \& Ryan, 2021; Ryan \& Reiljan, 2018). It is also one of the first applications of such affective polarization measures (supporter traits and social distancing) in a multi-party system. To date, it has not been established how well this measure corresponds to other measures of affective polarization (Druckman \& Levendusky, 2019), although differences have been observed, such as Iyengar et al., 2019). The present paper contributes to a growing research literature in this area in multi-party contexts (e.g. Knudsen's [2021] finding of greater sensitivity in Norway to a social distancing measure compared to a party like-dislike measure.

To identify participants' ingroup party, they first answered the item "What party do you like the best today?" and were given the choice of the current eight parties of the parliament. ${ }^{2}$ This method of defining the ingroup is less strict than the approach taken in previous research on the US, which only included partisans who explicitly stated

1) Data and information about the surveys are available from https://www.gu.se/en/som-institute.

2) The survey also allowed for the option of a free-text response which is not included in the analyses. 
that they were supporters of one party. Our measure of ingroup membership includes people that do not necessarily see themselves as supporters of the party they indicate as liking the most. This adaptation of ingroup party to the multi-party setting avoids assumptions about the meaning of party support, but is less strict and therefore may present a more demanding test of our hypothesis about the role of intergroup threat.

\section{Study 1}

\section{Method}

The first survey was collected by the SOM Institute in 2013. We chose to analyze this survey wave because the questions of interest were asked to the same participants, enabling us to run the relevant analyses. These questions were: concerns for different future societal challenges (independent variable), own position on a left-right scale (independent variable), dislike-like ratings for each party (the base of the dependent variable).

\section{Participants}

In the 2013 survey, 1,429 participants were included in our analyses. Mean age was $52(S D=17.48)$. There were 712 women (49.8\%), 714 men (50.0\%), and 3 who indicated other (these were excluded in further analyses due to the low number). Education level was distributed as follows: $246(17.2 \%)$ had low education, $393(27.5 \%)$ had mid-lower education, $322(22.5 \%)$ had mid-higher education, and 446 (31.2\%) had higher education. 22 (1.5\%) participants did not respond to the education question. The most preferred party of the participants was distributed as follows: Left Party: 88 (5.8\%), Social democrats: 425 (27.9\%), Green party: 157 (10.3\%), Center party: 58 (3.8\%), Liberals: 107 (7.0\%), Moderates: 390 (25.6\%), Christian Democrats: 60 (3.9\%), and Sweden democrats: $141(9.3 \%)$.

\section{Measures}

Affective polarization was measured using a like-dislike scale. First, participants indicated their own preferred party with the question, "Which party do you best prefer today?". They were shown a list of the eight parties in the Riksdag (the Swedish parliament), and were also given the choice to write another party ${ }^{3}$. Participants then rated all of the parties on a scale from -5 to +5 where -5 indicated "Strongly dislike" and +5 indicated "Strongly like". Because the participants first indicated their own preferred party, we can calculate the differences in ratings between the ingroup and the outgroup parties. To calculate an overall affective polarization score, we calculated the difference between the like-scoring for the participant's preferred party and each of the outgroup parties and then averaged the sum of these differences. The difference score could vary from -10 to +10 , and 0 indicates that the participant makes no difference between the outgroup and the ingroup. A negative value signifies outgroup preference, that is, a higher (more positive) rating on the outgroup compared to the ingroup. Positive values indicate ingroup favoritism, or more positive ratings of the ingroup compared to the outgroup.

Concerns for future challenges was measured with the question: "If you consider the situation today, how concerning do you yourself consider the following for the future?" Then followed a list of possible future prospects: Terrorism, Environmental destruction, Changes in the Earth's climate, Military conflicts, Increased number of refugees, Weakened democracy, Worsening ocean environment, The situation in Russia. Answers ranged from $1=$ Very concerned, to $4=$ Not at all concerned. The scale was reversed so that higher values indicate more concern. For the purpose of this article, we focus on the concern for increased number of refugees, which is likely to be perceived as an intergroup threat by right-wing individuals, and on concern for democracy, which is likely to be perceived as a threat by left-wing individuals.

3) Participants $(n=45,3 \%)$ who stated that they preferred another party than those currently represented in the Riksdag (Swedish parliament) were excluded from the analyses. No differences between the independent variables were found, except for age, where the other-party supporters were younger. 
Left-right identity was measured on a scale from $1=$ Clearly to the left to $5=$ Clearly to the right. This measure was used as a proxy for the type of ideological identity that would be associated with a particular concern being perceived as a threat, as described above. The distribution across this variable was as follows: Clearly to the left: $183(12.0 \%)$, Somewhat to the left: $320(21.0 \%)$, Neither to the left nor the right: 455 (29.9\%), Somewhat to the right: 415 (27.2\%), and Clearly to the right: $143(9.4 \%)$.

We also included some control variables. Gender was dummy coded with 1 representing women and 0 representing men, age, income and education. Income was measured as the total household income on a 3-point scale where 1 was 300 000 SEK or less, 2 was $301000-700000$ SEK, and 3 was more than 700000 SEK. Education was measured on a 4-point scale.

\section{Analyses}

The mean of the polarization index (like-dislike) was $4.22(S D=1.91)$, which is significantly higher than 0 as tested in a one-sample $t$-test, $t(1428)=83.46, S E=0.05, p<.001$. Hence, on an overall level, participants displayed a biased view in preference of their ingroup party.

Figure 1 shows affective polarization across all outgroup parties split on preferred party. As can be seen, affective polarization is strongest for the Sweden Democrats and the Left Party.

\section{Figure 1}

Affective Polarization (Like-Dislike) Across Preferred Party

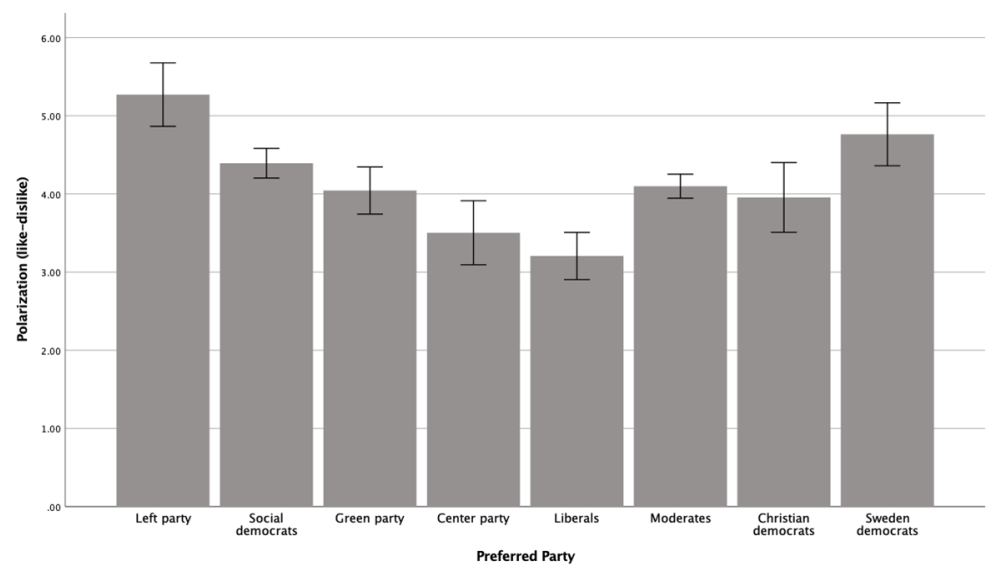

Note. Error bars indicate 95\% confidence intervals. See the Appendix for significance tests between all parties.

Figure 2 shows mean polarization for the like-dislike measure across all outgroup parties split on participants' own ideology on the left-right scale. As can be seen, individuals at the end-points of the scale (clearly to the left or the right) display the highest polarization.

Our main expectation, based on intergroup threat theory, is that affective polarization should increase when a societal challenge is perceived as a potential threat. We suggest that ideological identification could be used as a proxy to understand which respondents will most likely perceive a certain type of challenge as a potential threat. Thus, we expect an interaction between ideological identification and type of challenge. To test this expectation, we perform a regression analysis, with the polarization index (like-dislike) as the outcome variable. We enter the refugee item and the weakened democracy item into the regression analysis, controlling for age, gender, education, income and left-right identity, and we include the two-way interactions between ideology and type of concern. The results are shown in Table 1. 
Figure 2

Affective Polarization (Like-Dislike) Across Left-Right Ideology

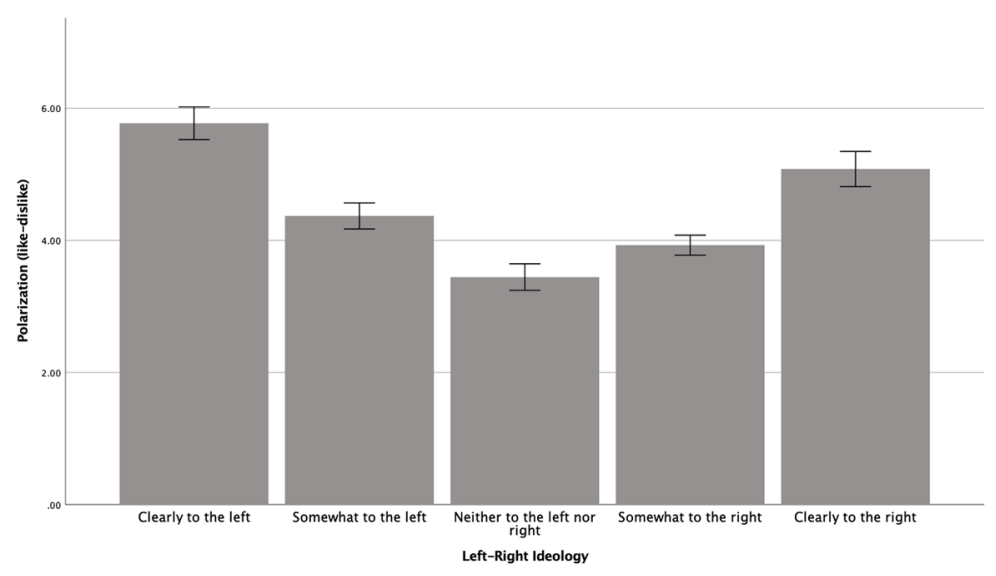

Note. Error bars indicate 95\% confidence intervals.

Table 1

Regression Predicting Affective Polarization (Like-Dislike)

Affective polarization (like-dislike)

$N=1,341$

\begin{tabular}{lcc} 
& Model 1 & Model 2 \\
\cline { 2 - 3 } Predictor & $\boldsymbol{B}(\boldsymbol{S E})$ & $\boldsymbol{B}(\boldsymbol{S E})$ \\
\hline Constant & $4.36(0.36)^{* * *}$ & $3.05(0.62)^{* * *}$ \\
Gender & $-0.41(0.10)^{* *}$ & $-0.40(0.10)^{* * *}$ \\
Age & $0.001(0.003)$ & $0.001(0.003)$ \\
Education & $0.08(0.05)$ & $0.06(0.05)$ \\
Income & $0.05(0.08)$ & $0.05(0.08)$ \\
Left-right & $-0.23(0.05)^{* * *}$ & $0.17(0.17)$ \\
Democracy concern & $0.07(0.06)$ & $0.88(0.16)^{* * *}$ \\
Refugees concern & $0.08(0.06)$ & $-0.31(0.15)^{*}$ \\
Democracy $\times$ Left-right & & $-0.25(0.05)^{* * *}$ \\
Refugee $\times$ Left-right & & $0.13(0.05)^{* *}$ \\
\hline & $R_{\text {adj. }}^{2}=.03^{* *}$ & $R_{\text {adj. }}^{2}=.05^{* * *}$ \\
& & $\Delta R^{2}=.02^{* * *}$ \\
\hline
\end{tabular}

Note. Gender is dummy coded with $1=$ women, $0=$ men.

${ }^{*} p<.05 .{ }^{* *} p<.01 .{ }^{* * *} p<.001$.

In relation to our hypothesis that there should be an interaction between type of concern and left-right identity, the interaction terms in Model 2 were both significant. The interactions are plotted in Figure 3a and Figure 3b, where left-right ideology is evaluated at $1 S D$ above and below the mean. The only control variable that was significant was gender, such that women (coded as 1) showed less affective polarization compared to men (coded as 0 ). There was also a main effect of left-right ideology, such that leaning to the right was associated with less polarization. There were no main effects of democracy concern or refugee concern. 
Figure 3a

Interaction Effects of Refugee Concern and Left-Right Ideology on Affective Polarization (Like-Dislike)

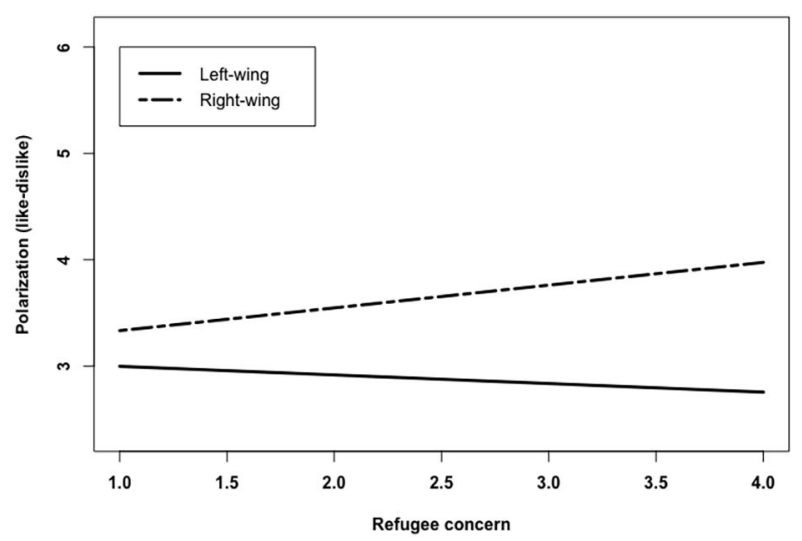

Note. The Y-axis is cut at the mean of polarization \pm 1 standard deviation.

\section{Figure $3 b$}

Interaction Effects of Democracy Concern and Left-Right Ideology on Affective Polarization (Like-Dislike)

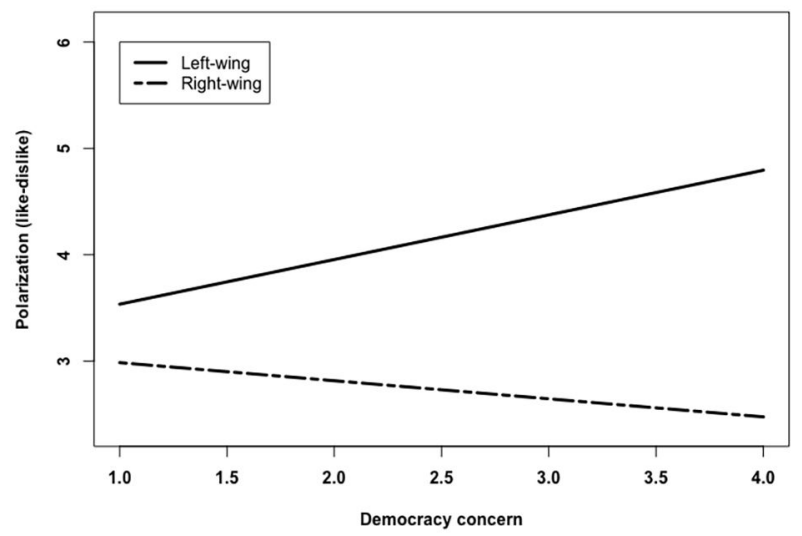

Note. The Y-axis is cut at the mean of polarization \pm 1 standard deviation.

We also ran simple slope analyses to test whether the slopes were significant at $1 S D$ above and below the mean of left-right ideology. For Refugee concerns the simple slope for the right-wing participants was significant, $B=0.21, S E=$ $0.08, p=.005$, while the slope for the left-wing participants was not, $B=-0.08, S E=0.08, p=.28$. These are in line with expectations that once a concern is interpreted as a threat, it increases affective polarization. For democracy concerns, the slope for the left-wing participants was significant, $B=0.42, S E=0.07, p<.001$, as expected. An unexpected finding was that the slope for the right-wing participants was also significant in the opposite direction, $B=-0.17, S E=$ $0.02, p<.001$, indicating that for right-leaning individuals, a greater concern for democracy is associated with lower polarization.

In terms of magnitude, a change from the lowest to the highest observed democracy concern (from 1 to 4 ) for left-wing respondents is associated with a change in like-dislike polarization from about the $33^{\text {rd }}$ to about the $68^{\text {th }}$ percentile of the observed data. A similar change in refugee concern for right-wing respondents is associated with a change in like-dislike polarization from about the $30^{\text {th }}$ to about the $47^{\text {th }}$ percentile of the observed data.

In sum, the results from this first study support our hypothesis that threat is associated with higher affective polarization. This was shown by participants leaning to the left being increasingly polarized the greater their concern 
about democracy and participants leaning to the right being increasingly polarized the greater their concern about refugees.

\section{Study 2}

\section{Method}

Although the like-dislike scale has been extensively used to measure affective polarization (e.g. Wagner, 2021), this measure may also capture other phenomena since it has often been used to gauge individuals' and parties' ideological positions. For our second study, we collected new data that allow us to include the measures of affective polarization most often used in studies conducted in a US context. The second survey, collected in 2019 in collaboration with the SOM Institute, includes a measure of trait ratings and a social distance measure (about a child's marriage to an outgroup member) similar to those used to capture affective polarization in previous research on the US (e.g. Iyengar et al., 2012). ${ }^{4}$

\section{Participants}

In the specific part of the survey we analyze, 1343 participants were included. Mean age was 52 years $(S D=18.56)$, and there were 667 women (49.7\%), 673 men (50.2\%), and 3 people responded "other" (0.2\%). Education was distributed as follows: $9(0.7 \%)$ had not finished basic schooling, $152(11.3 \%)$ had only basic schooling, 130 (9.7\%) had studied at high school level, 241 (17.9\%) had graduated from high school, 181 (13.5\%) had some post-high-school education that not included college/university, $156(11.6 \%)$ had studied at college or university, 431 (32.1) had graduated from college or university, and 27 (2\%) had studied or graduated from a PhD program (16 (1.2\%) missing). The participants indicated their most preferred party and the distribution was as follows: Left party: 119 (8.2\%), Social democrats: 356 (24.6\%), Green party: 83 (5.7\%), Center party: 153 (10.6\%), Liberals: 65 (4.5\%), Moderates: 232 (16.0\%), Christian Democrats: 103 (7.1\%), and Sweden Democrats: 205 (14.1\%).

\section{Measures}

Affective polarization was measured with trait ratings and the social distance measure. First, participants indicated their most preferred party as in Study $1^{5}$. This variable is used to identify the respondent's ingroup affiliation. Then they were asked to rate all the parties' supporters on four different traits. The traits were honest, intelligent, prejudiced, and selfish. The question read: “To what extent do you consider supporters of the following parties to be [trait]?", with responses on a 7-point Likert scale from $1=$ Very little to $7=$ Very much. Our social distancing measure is based on the question, how upset would you be if you had a daughter or son who married a supporter of the following parties? For each party, participants indicated how upset they would be on a scale from $1=$ Not upset at all to $7=$ Very upset.

We subtracted ingroup ratings from outgroup ratings to create mean indices where higher values indicate more bias (increased distancing) in favor of the ingroup. For each participant, the differences between the evaluation of the preferred party and all other parties were calculated separately for each outparty on each provided attribute. From these differences, averages were calculated over the different attributes to create the index for polarization on positive traits (honest, intelligent) and on negative traits (selfish, prejudiced). The averages of the positive and the reversed negative indices were calculated, resulting in several polarization indices per participant - one for each outparty. The total polarization index is the mean of the differences between the ingroup and the outgroup ratings for every participant. Higher values on the polarization index indicate stronger intergroup differentiation in favor of the ingroup, between the ingroup and all of the outgroup parties. The polarization indices can range from -6 to +6 , where 0 indicates that

4) As the like-dislike question was not asked to the same participants as the trait ratings or social distance questions in the 2019 survey, we cannot make any direct comparisons. The participants who were asked the like-dislike question were also not asked the concern items, so that we cannot include the like-dislike scale as a dependent variable in the following analyses.

5) Again, we tested the difference between participants who supported another party $(n=31,2.1 \%)$ than the ones in the Riksdag on the independent variables and again, only age differed where the other-party supporters were younger. 
the participant makes no difference between the outgroup and the ingroup. Again, a negative value signifies outgroup preference, that is, a higher (more positive) rating on the outgroup compared to the ingroup. Positive values indicate ingroup favoritism, or more positive ratings of the ingroup compared to the outgroup.

Left-right identity was, as in the previous survey, measured on a 5-point scale from $1=$ Clearly to the left to $5=$ Clearly to the right. This is used to capture the ideological identity of respondents that would condition which threats we would expect them to perceive. The distribution of participants across the options was as follows: Clearly to the left: $160(11.0 \%)$, Somewhat to the left: $312(21.5 \%)$, Neither to the left nor the right: $406(28.0 \%)$, Somewhat to the right: 379 (26.2\%), and Clearly to the right: $178(12.3 \%)$.

Concern for future challenges was measured with the same question as in Study 1, but the items were somewhat different in this survey: economic crisis, military conflicts, political extremism, global epidemics, organized crime, increased number of refugees, increased use of narcotics, and limits on the freedom of speech. In this study, we again chose to look at concerns for increased number of refugees as in Study 1, but also concerns about political extremism (the item on a concern for democracy was not included). Increased political extremism is likely to be seen as an intergroup threat if participants are concerned about the other side's potential to inflict harm on the own group, which makes it a relevant item in the present context.

We also included some control variables. Gender was dummy coded with $1=$ women and $0=$ men, age, income and education. Income was measured as the total household income on a 12-point scale increasing in 100000 SEK per unit from $1=100000$ SEK or less to $12=$ more than 1100000 SEK. Education was measured on an 8-point scale, gauging participants' highest level of education, from $1=$ not completed basic schooling to $8=$ Doctoral degree.

\section{Analyses}

The mean of the affective polarization index (traits) was $1.28(S D=1.22)$. This value is significantly different from 0 as tested in a one-sample $t$-test, $t(1342)=38.45, S E=.03, p<.001$. The mean of the social distance measure was $0.88(S D=$ 1.15), which is also significantly different from $0, t(1337)=28.02, S E=0.03, p<.001$. Again, this indicates that overall, participants displayed a slightly biased view in preference of their ingroup party.

Figure $4 \mathrm{a}$ and Figure $4 \mathrm{~b}$ show affective polarization, measured as trait ratings and using the social distance measure, across all outgroup parties split by preferred party. Here we see that affective polarization is strongest for the Sweden Democrats and the Left Party, which mirrors the effects from Study 1. That is, when voters who prefer other parties are asked to evaluate supporters of these two parties, they are strongly biased and show clear distancing.

Figure 4a

Affective Polarization (Traits) Across Preferred Party

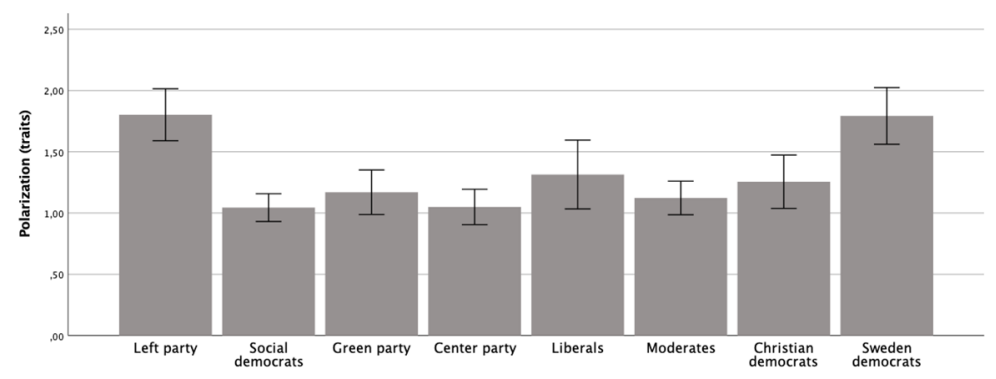

Note. Error bars indicate $95 \%$ confidence intervals. See the Appendix for significance tests between all parties. 


\section{Figure 4b}

Affective Polarization (Social Distance) Across Preferred Party

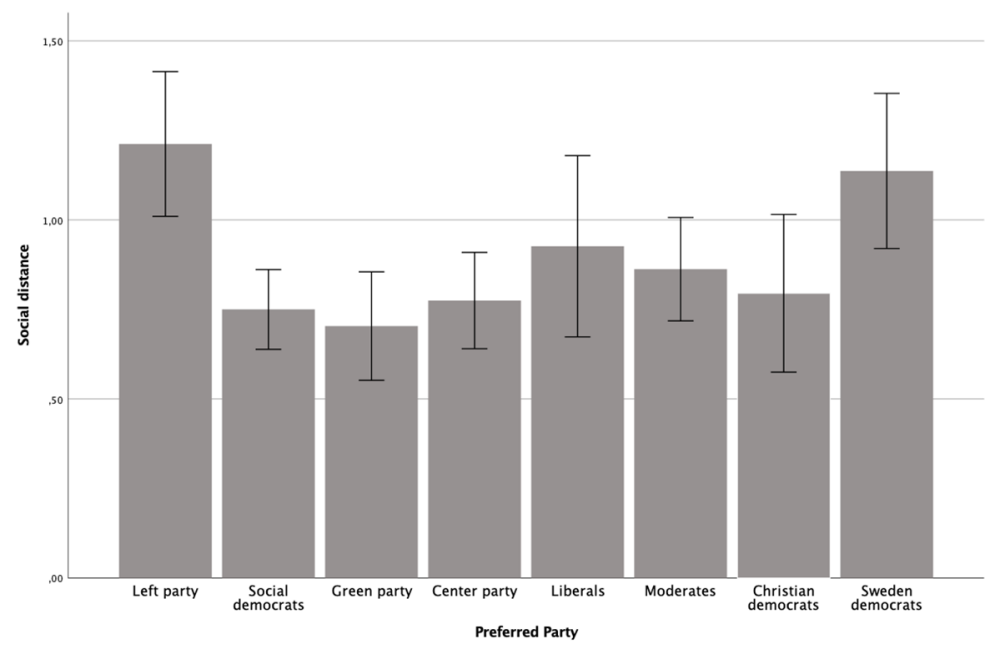

Note. Error bars indicate 95\% confidence intervals. See the Appendix for significance tests between all parties.

Moreover, the two measures of affective polarization mirror each other, though the values are lower for the social distance (marriage) question presented in Figure 4b. The confidence intervals are also wider for this measure, indicating less agreement.

Figure 5a and Figure 5b show mean polarization across all outgroup parties split on participants' ideology on the left-right scale for both trait ratings (upper) and social distance (lower). The figures mirror each other and the previous figures split on preferred party in the sense that the most extreme positions on this scale (clearly to the left/right) are also related to the strongest polarization or bias against outgroup parties. Finally, these figures are also consistent with those in Study 1.

\section{Figure 5a}

Affective Polarization (Traits) Across Left-Right Ideology

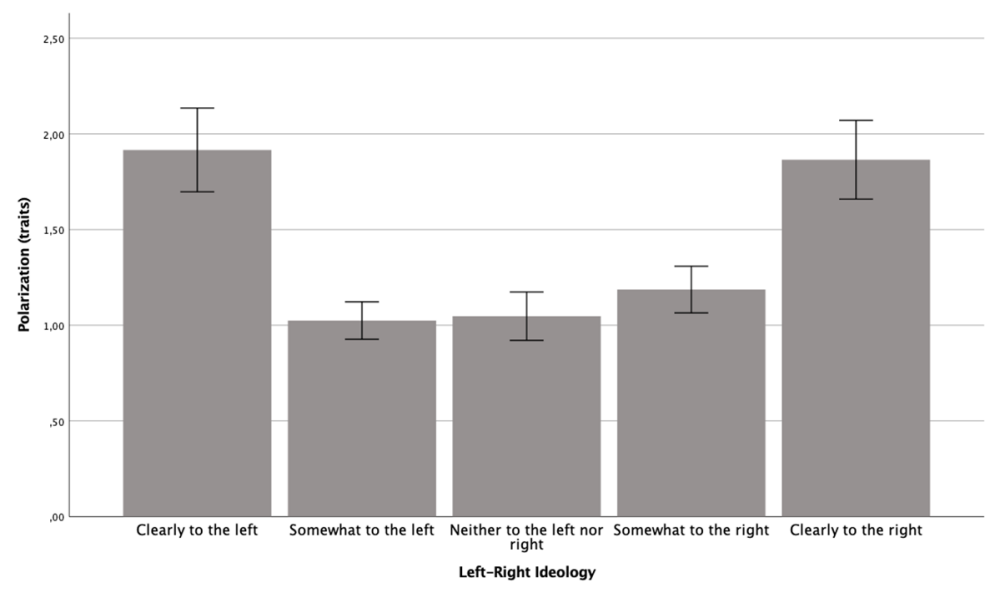

Note. Error bars indicate $95 \%$ confidence intervals. 


\section{Figure 5b}

Affective Polarization (Social Distance) Across Left-Right Ideology

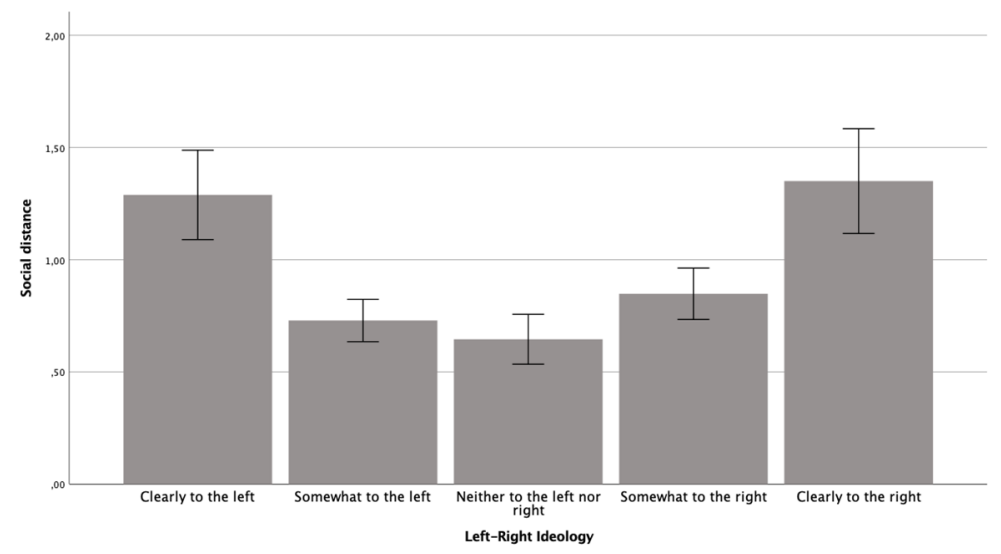

Note. Error bars indicate $95 \%$ confidence intervals.

We again tested the hypothesis that affective polarization should increase when individuals perceive a threat, which we argue is captured by the interaction between a specific type of societal challenge concern and ideological identification. We performed two separate regression analyses: one with the affective polarization index using the traits measure as the outcome variable and one with the social distance measure as the outcome variable. We entered the two concerns (extremism and refugees) and their interactions into the regression analyses, controlling for age, gender, education, income and left-right position. The results are shown in Table 2. As can be seen, the main threat predictors of left- and right-wing concerns were significant across the board; increased concern, regardless of type, was associated with higher affective polarization, using both types of polarization measures.

Table 2

Regression Predicting Affective Polarization (Traits and Social Distance)

\begin{tabular}{|c|c|c|c|c|}
\hline \multirow[b]{3}{*}{ Predictor } & \multicolumn{2}{|c|}{$\begin{array}{l}\text { Affective polarization (traits) } \\
\qquad N=1,214\end{array}$} & \multicolumn{2}{|c|}{$\begin{array}{l}\text { Affective polarization (social distance) } \\
\qquad N=1,188\end{array}$} \\
\hline & Model 1 & Model 2 & Model 1 & Model 2 \\
\hline & $B(S E)$ & $B(S E)$ & $B(S E)$ & $B(S E)$ \\
\hline Constant & $0.98(0.25)^{* * *}$ & $0.87(0.52)$ & $0.62(0.24)^{*}$ & $1.24(0.51)^{*}$ \\
\hline Gender & $-0.22(0.07)^{* *}$ & $-0.21(0.07)^{* *}$ & $-0.15(0.07)^{*}$ & $-0.13(0.07)^{*}$ \\
\hline Age & $-0.002(0.002)$ & $-0.002(0.002)$ & $-0.004(0.002)^{*}$ & $-0.004(0.002)$ \\
\hline Education & $-0.02(0.02)$ & $-0.02(0.02)$ & $-0.01(0.02)$ & $-0.01(0.02)$ \\
\hline Income & $-0.004(0.01)$ & $-0.01(0.01)$ & $0.02(0.01)$ & $0.02(0.01)$ \\
\hline Left-right & $-0.01(0.03)$ & $-0.08(0.15)$ & $0.01(0.03)$ & $-0.28(0.15)$ \\
\hline Extremism concern & $0.10(0.04)^{* *}$ & $0.57(0.12)^{\star * *}$ & $0.08(0.04)^{*}$ & $0.31(0.12)^{* *}$ \\
\hline Refugees concern & $0.12(0.04)^{\star *}$ & $-0.40(0.09)^{* * *}$ & $0.08(0.04)^{*}$ & $-0.43(0.09)^{* * *}$ \\
\hline Extremism $\times$ Left-right & & $-0.14(0.03)^{* * *}$ & & $-0.07(0.03)^{*}$ \\
\hline \multirow[t]{3}{*}{ Refugee $\times$ Left-right } & & $0.18(0.03)^{* * *}$ & & $0.17(0.03)^{* * *}$ \\
\hline & $R_{\text {adj. }}^{2}=.01^{* *}$ & $R_{\mathrm{adj} .}^{2}=.06^{* * *}$ & $R_{\text {adj. }}^{2}=.01^{* *}$ & $R_{\text {adj. }}^{2}=.04^{* * *}$ \\
\hline & & $\Delta R^{2}=.05^{* * *}$ & & $\Delta R^{2}=.03^{* * *}$ \\
\hline
\end{tabular}

Note. Gender is dummy coded with $1=$ women, $0=$ men.

${ }^{*} p<.05 .{ }^{* *} p<.01 .{ }^{* * *} p<.001$. 
Looking at the control variables, gender significantly affected overall polarization such that women (coded as 1) tended to score lower on both polarization measures compared to men. Age had a small but significant effect on the social distance measure such that higher age was related to lower polarization. No other demographic predictors were significant here.

As described above, we expected an interaction between type of concern and political position. In Table 2 (Model 2), we show results for the interaction between concern for political extremism and political orientation and concern for refugees and political orientation. As can be seen in these models, both interaction terms are significant for both types of polarization measures. The results are plotted in Figure $6 \mathrm{a}$ and Figure $6 \mathrm{~b}$, and Figure $7 \mathrm{a}$ and Figure $7 \mathrm{~b}$. The interactions are evaluated at one standard deviation above and below the mean of left-right ideology.

\section{Figure 6a}

Interaction Effects of Refugee Concern and Left-Right Ideology on Affective Polarization (Traits)

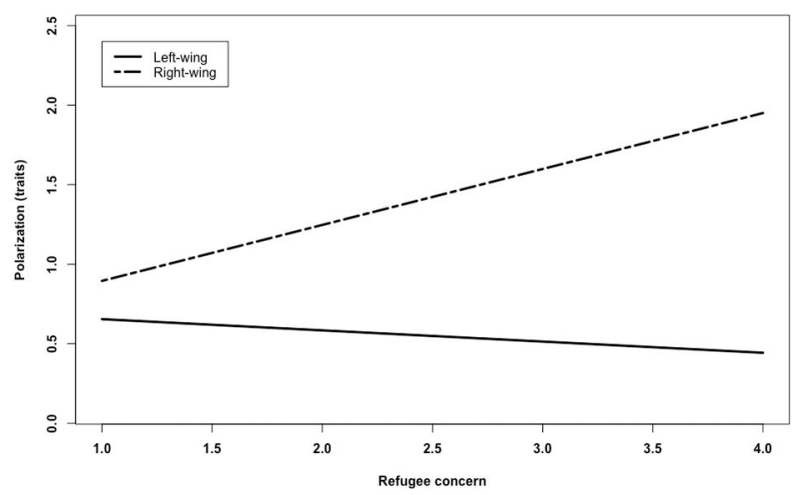

Note. The Y-axis is cut at the mean of polarization \pm 1 standard deviation.

\section{Figure 6b}

Interaction Effects of Extremism Concern and Left-Right Ideology on Affective Polarization (Traits)

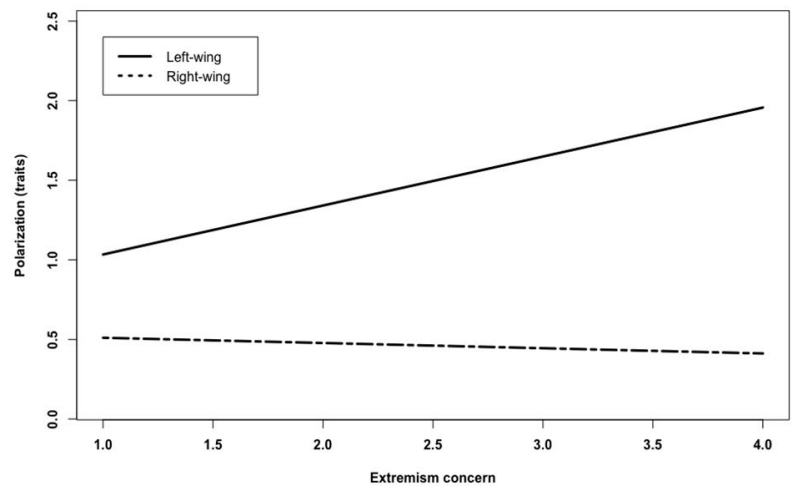

Note. The Y-axis is cut at the mean of polarization \pm 1 standard deviation.

As can be seen in Figure 6a and Figure 6b, where we present results using the traits variable as a measure of affective polarization, the interactions confirmed our expectations that the effect of concerns on polarization would depend on whether the individual was identified as left or right. For concerns for political extremism, the effect for left-wing individuals is clearly positive, with polarization increasing with greater concern about extremism, but not for right-wing individuals. For refugee concerns, the effect was positive for right-wing individuals, who became more polarized, the more concerned they were with an increase of refugees. 
We also ran simple slope analyses to test which slopes had significant effects. For extremism concerns, the slope for left-wing individuals was significant, $B=0.35, S E=0.06, p<.001$, while it was not for right-wing individuals, $B=0.04$, $S E=0.05, p=.45$. The opposite was true for refugee concerns; the right-wing slope was significant, $B=0.35, S E=0.10, p$ $<.001$, while it was not for left-wing participants, $B=-0.07, S E=0.07, p=0.32$.

Substantively, a change from the lowest to the highest observed extremism concern (from 1 to 4) for left-wing respondents is associated with a change in trait polarization from about the $50^{\text {th }}$ to about the $75^{\text {th }}$ percentile of the observed data. A similar change in refugee concern for right-wing respondents is associated with a change in trait polarization from about the $45^{\text {th }}$ to about the $75^{\text {th }}$ percentile of the observed data.

\section{Figure 7a}

Interaction Effects of Refugee Concern and Left-Right Ideology on Affective Polarization (Social Distance)

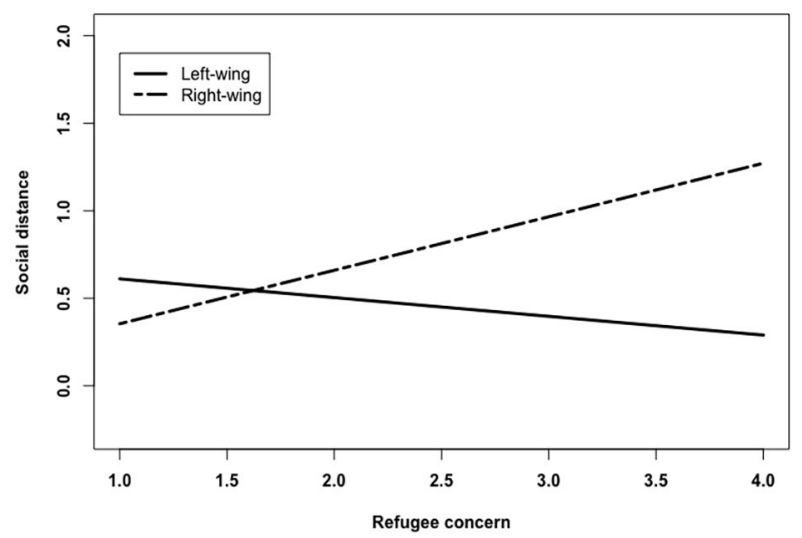

Note. The Y-axis is cut at the mean of polarization \pm 1 standard deviation.

\section{Figure $7 b$}

Interaction Effects of Extremism Concern and Left-Right Ideology on Affective Polarization (Social Distance)

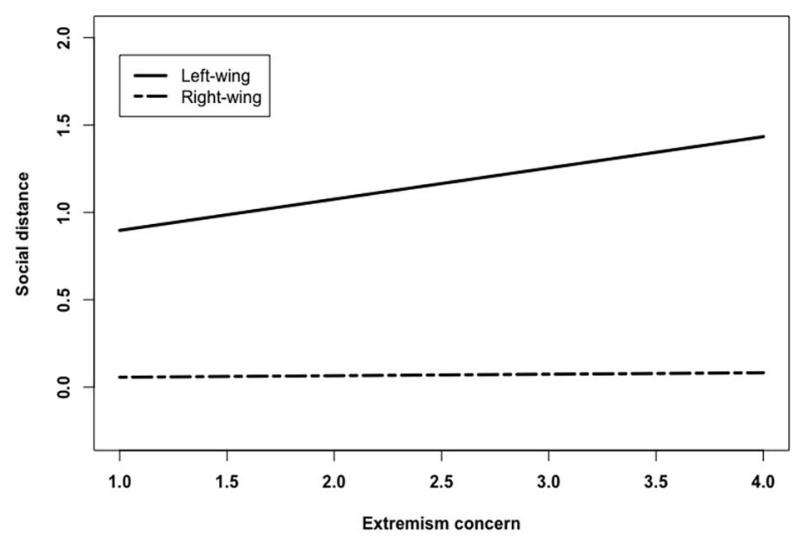

Note. The Y-axis is cut at the mean of polarization \pm 1 standard deviation.

As can be seen in Figure 7a and Figure 7b, where we present the analyses using the social distancing question as the dependent variable, the pattern largely followed that found for the traits, although a bit weaker for extremism concerns. Still, the simple slopes were significant such that for extremism concerns, the slope for left-wing participants was significant, $B=0.18, S E=0.06, p=.004$, while the right-wing slope was not, $B=0.05, S E=0.30, p=.88$. Conversely, for refugee concerns, the slope for right-wing participants was significant, $B=0.31, S E=0.09, p=.001$, and non-significant for left-wing participants, $B=-0.10, S E=0.06, p=.09$. 
Hence, for left-wing individuals, an increased concern for extremism was associated with higher polarization, while for right-wing individuals, increased concern about refugees was associated with higher polarization. Substantively, a change from the lowest to the highest observed extremism concern (from 1 to 4 ) for left-wing respondents is associated with a change in social distance polarization from about the $65^{\text {th }}$ to about the $75^{\text {th }}$ percentile of the observed data. A similar change in refugee concern for right-wing respondents is associated with a change in social distance polarization from about the $45^{\text {th }}$ to about the $73^{\text {rd }}$ percentile of the observed data.

Taken together, the results indicate that for individuals more likely perceive a threat, an increase in affective polarization is observed. In this second study, we see this pattern for both the trait and social distancing measures of affective polarization.

\section{General Discussion}

We had several aims with this paper. First, we wanted to explore individual-level features that explain affective polarization in a multi-party system and to anchor this in the framework of social identity theory (Tajfel \& Turner, 1986). Our results show that the Swedish voters display affective polarization in a manner consistent with the findings of previous research both in a Swedish context (Boxell et al., 2020; Reiljan \& Ryan, 2021; Renström et al., 2020) and in other multi-party systems, such as the Netherlands (Harteveld, 2021).

However, we extend this previous research in Sweden and other multi-party contexts beyond the most commonly used measure, the like-dislike scale, testing our hypothesis using measures similar to those in previous studies in the US context-specifically, trait rating scales and a social distance measure. While the findings in the two studies mirror one another, we believe the findings from the study using trait and social distance measures are especially important because the like-dislike scale may be more likely to capture differences in ideological opinions and not only reflect biased judgements of the party's supporters. That is, perceiving others as dishonest or unintelligent has different implications for potential cross-party cooperation than the more general disliking of other parties, which may also result from policy disagreement. Therefore, analyzing the trait ratings and social distancing measure may allow us to get closer to capturing the mechanisms behind affective polarization than the analysis of a like-dislike measure.

Our findings support the previous research in observing affective polarization in Sweden (Boxell et al., 2020; Reiljan \& Ryan, 2021), despite that these studies differ by using the like-dislike scale measure and left-right blocs with the Sweden Democrats separated (Reiljan \& Ryan, 2021), or by restricting the index to be based on the two largest parties only (Boxell et al., 2020). Although we find similar patterns using both the like-dislike scale, the trait ratings and the social distance measure, the results have greater comparability to many findings in the literature on the US case.

Also, we note that our polarization index is based on a composite of outgroup ratings for all other parties than the participant's own most preferred party. We believe that by letting all outgroup parties represent the outgroup ratings, the effects are likely to be weaker compared to looking, for instance, at only two opposing parties because the composite outgroup measure includes parties leaning in the same ideological direction. Since this line of research is still relatively new, there is not yet a standard method to measure affective polarization in a multi-party system. One potential survey design that might provide stronger effects would be to allow a 'least favorite party' selection to provide researchers with a clear outgroup party to calculate affective polarization score. Such an approach would be simpler to measure and calculate, although perhaps less nuanced.

Our results show that the overall polarization index, regardless of measure, was significantly different from 0 , indicating that citizens hold more positive views of their ingroup party than their outgroup party. They are also reluctant to socialize with supporters of outgroup parties. To understand what predicts affective polarization it is necessary to go back to the roots of affective polarization, which is the social identity theory (Tajfel \& Turner, 1986). The theory explicitly states that stronger identification with a group increases intergroup differentiation. Considering that even arbitrary social groups have been shown to elicit intergroup differentiation (Turner \& Reynolds, 2010) and that political identity should be quite relevant to individuals, it is reasonable to expect that identification with a party would evoke intergroup differentiation and hence also affective polarization. This notion also aligns with previous research 
showing that (political) attitudes are sufficient to create psychologically meaningful social groups (Bäck et al., 2010; Bäck, 2013). It is also natural that the strength of partisan identity should be related to the level of affective polarization.

Drawing on intergroup threat theory (e.g., Stephan et al., 2009), we expected that perceptions of threat should elicit affective polarization. The operationalization of threat perception in this article lies in the intersection between being concerned over a specific future challenge and left-right identification. We argue that concern for different potential challenges is not enough to evoke intergroup distancing and affective polarization. Instead, this concern must be perceived as a potential threat to the ingroup associated with the outgroups. The capacity of politically relevant stimuli to affect attitudes depends heavily on evoking feelings of being threatened (Marcus et al., 2000). Therefore we expected that identification with the left or right would influence what events or challenges are perceived as threats.

Specifically, we expected that immigration would be seen as threatening to the right, and the risk of a weakened democracy or increased political extremism would be more threatening for individuals to the left. Even though the extent to which these different concerns have the potential to constitute intergroup threats may be debatable, an increased number of immigrants is clearly able to provoke perceptions of an intergroup threat (Stephan et al., 2009, 2015) since it concerns the possibility that another group exerts influence over the situation of the ingroup. When it comes to the state of the democracy or the concern for political extremism, the intergroup aspect is not as clear. However, Sweden has experienced a growth in right-wing extremism (SÄPO, 2019) and groups that question democratic values, minority rights, carrying a tail of more extreme individuals who do not shy from using violence. Hence, the state of the democracy and a potential increase in political extremism could therefore be interpreted as an intergroup threat against the left. This interpretation is also supported in our results, given that increased concern for democracy and for political extremism was associated with higher levels of polarization for left-wing individuals but not right-wing individuals.

In sum, our results make several important contributions to the literature. Most importantly, we show that perceived intergroup threat is an important explanation of affective polarization. Another interesting finding is related to the measures of affective polarization used here - in contrast to previous literature (Druckman \& Levendusky, 2019), we found that the effects for the trait ratings and the social distance measure mirrored each other. It should be noted that the effects were weaker for the social distance measure compared to the trait ratings. This is not surprising since the social distance measure taps into the prospect of social connections with specific individuals of another party, while the general trait ratings refer rather to preconceptions about a group in general - a stereotype of outgroup partisans.

\section{Limitations of the Study}

In this study, we operationalized threat perception as the interaction between concerns for future challenges that could potentially constitute an intergroup threat and left-right ideology, which we argue will be associated with what is perceived as a threat. This is clearly an indirect measure, however, and it would be desirable for future research to tap into intergroup threat perceptions more directly. Most notably, we cannot be certain of causal relationships since we here rely on a cross-sectional design. We thus suggest that future research should perform studies based on experimental designs where potential threats are manipulated, for example using statements by political representatives framing specific societal issues as threats. Such experimental studies would also allow us to assess the causal mechanism that explains a relationship between threat perceptions and affective polarization, focusing on emotional reactions. This would further increase our understanding of the role of intergroup threat and affective polarization. Drawing on previous research, we would expect that anger increases polarization, since it has been shown that anger is a high-arousal emotion related to decreased cognitive processing and increased reliance on stereotypes (e.g. Brader \& Marcus, 2013). Hence, individuals who interpret a message as threatening are likely to feel angry, which may result in positive bias towards their ingroup and negative bias against their outgroup.

Also, this study operationalizes ingroup party differently than some previous research, focusing on which party the participant likes the most. The benefit of such a measure is that we can include more participants in the analysis since most state that they like one of the parties more. Importantly, this measure is only used to establish the groups for which differentiation is measured on our affective polarization indicators. The results may be weaker than if only highly identified partisans were included, yet we still find the expected results with this approach. 
Another potential limitation of this study is that we have only analyzed the role of intergroup threat in explaining affective polarization in one specific context. Contextual features may clearly matter for understanding why certain societal challenges are perceived as threats and ultimately influence affective polarization in a society. We have here focused on only one societal context, the Swedish one, where immigration was up until 2015, not seen as a societal challenge by most political actors. Studies of Swedish voters show that the immigration issue has become more salient over time and that many voters have become more negative towards immigration since 2016 - after a large number of refugees came to Sweden during 2015, mainly from Syria (see Demker, 2021). That our main results are consistent between two studies of two different political contexts - with one performed before the refugee crisis of 2015 and one performed after this crisis - provides some evidence for the generalizability of our results. However, future research should evaluate whether the hypothesis about intergroup threat and affective polarization is supported in other contexts.

Funding: This research was supported by a grant from the Swedish Research Council grant number: 2017-02609.

Acknowledgments: The authors would like to thank the SOM institute for a fruitful collaboration in gathering the data used in this article. In addition, the authors would like to thank Yvonne Schmeisser for help with data handling, and Alexander Ryan for helpful comments on the manuscript.

Competing Interests: The authors have declared that no competing interests exist.

Data Availability: Data and information about the surveys are available from https://www.gu.se/en/som-institute.

\section{References}

Bäck, E. A. (2013). Position towards the status quo: Explaining differences in intergroup perceptions between left- and right-wing affiliates. Journal of Applied Social Psychology, 43, 2073-2082. https://doi.org/10.1111/jasp.12160

Bäck, E. A., Esaiasson, P., Gilljam, M., \& Lindholm, T. (2010). Biased attributions regarding the origins of preferences in a group decision situation. European fournal of Social Psychology, 40, 270-281. https://doi.org/10.1002/ejsp.618

Boxell, L., Gentzkow, M., \& Shapiro, J. M. (2020). Cross-country trends in affective polarization (NBER working paper no. w26669). National Bureau of Economic Research. https://doi.org/10.3386/w26669

Brader, T., \& Marcus, G. E. (2013). Emotion and political psychology. In L. Huddy, D. O. Sears, \& J. S. Levy (Eds.), The Oxford handbook of political psychology (2nd ed., pp. 165-204). Oxford, United Kingdom: Oxford University Press.

Demker, M. (2021). Vilka var det som ändrade sig om flyktingpolitiken efter 2015? In U. Andersson, A. Carlander, M. Grusell, \& P. Öhberg (Eds.), Ingen anledning till oro (?) (pp. 317-331). Göteborg, Sweden: SOM-institutet.

Druckman, J. N., \& Levendusky, M. S. (2019). What do we measure when we measure affective polarization? Public Opinion Quarterly, 83, 114-122. https://doi.org/10.1093/poq/nfz003

Garrett, R. K., Gvirsman, S. D., Johnson, B. K., Tsfati, Y., Neo, R., \& Dal, A. (2014). Implications of pro- and counter-attitudinal information exposure for affective polarization. Human Communication Research, 40, 309-332. https://doi.org/10.1111/hcre.12028

Gidron, N., Adams, J., \& Horne, W. (2019). Toward a comparative research agenda on 28 affective polarization in mass publics. APSA Comparative Politics Newsletter, 29, 30-36.

Gidron, N., Adams, J., \& Horne, W. (2020). American affective polarization in comparative perspective. In F. E. Lee (Ed.), Elements in American politics. Cambridge University Press. https://doi.org/10.1017/9781108914123

Hainmueller, J., \& Hopkins, D. J. (2014). Public attitudes toward immigration. Annual Review of Political Science, 17(1), $225-249$. https://doi.org/10.1146/annurev-polisci-102512-194818

Harteveld, E. (2021). Fragmented foes: Affective polarization in the multi-party context of the Netherlands. Electoral Studies, 71, Article 102332. https://doi.org/10.1016/j.electstud.2021.102332

Haslam, S. A., Ellemers, N., Reicher, S. D., Reynolds, K. J., \& Schmitt, M. T. (2010). The social identity perspective tomorrow: Opportunities and avenues for advance. In T. Postmes \& N. R. Branscombe (Eds.), Rediscovering social identity (pp. 357-379). New York, NY, USA: Psychology Press. 
Huddy, L., Mason, L., \& Aarøe, L. (2015). Expressive partisanship: Campaign involvement, political emotion, and partisan identity. The American Political Science Review, 109(1), 1-17. https://doi.org/10.1017/S0003055414000604

Iyengar, S., Lelkes, Y., Levendusky, M., Malhotra, N., \& Westwood, S. J. (2019). The origins and consequences of affective polarization in the United States. Annual Review of Political Science, 22, 129-146. https://doi.org/10.1146/annurev-polisci-051117-073034

Iyengar, S., Sood, G., \& Lelkes, Y. (2012). Affect, not ideology: A social identity perspective on polarization. Public Opinion Quarterly, 76(3), 405-431. https://doi.org/10.1093/poq/nfs038

Iyengar, S., \& Westwood, S. J. (2015). Fear and loathing across party lines: New evidence on group polarization. American fournal of Political Science, 59, 690-707. https://doi.org/10.1111/ajps.12152

Knudsen, E. (2021). Affective polarization in multi-party systems? Comparing affective polarization towards voters and parties in Norway and the United States. Scandinavian Political Studies, 44(1), 34-44. https://doi.org/10.1111/1467-9477.12186

Lauka, A., McCoy, J., \& Firat, R. B. (2018). Mass partisan polarization: Measuring a relational concept. The American Behavioral Scientist, 62(1), 107-126. https://doi.org/10.1177/0002764218759581

Lavine, H., Lodge, M., \& Freitas, K. (2005). Threat, authoritarianism and selective exposure to information. Political Psychology, 26, 219-244. https://doi.org/10.1111/j.1467-9221.2005.00416.x

Lelkes, Y. (2021). Policy over party: Comparing the effects of candidate ideology and party on affective polarization. Political Science Research and Methods, 9(1), 189-196. https://doi.org/10.1017/psrm.2019.18

Lelkes, Y., \& Westwood, S. J. (2017). The limits of partisan prejudice. The fournal of Politics, 79(2), 485-501. https://doi.org/10.1086/688223

Levendusky, M., \& Malhotra, N. (2016). Does media coverage of partisan polarization affect political attitudes? Political Communication, 33, 283-301. https://doi.org/10.1080/10584609.2015.1038455

Lindvall, J., Bäck, H., Dahlström, C., Naurin, E., \& Teorell, J. (2017). Samverkan och strid i den parlamentariska demokratin. Stockholm, Sweden: SNS Förlag.

Mackie, D. M., Devos, T., \& Smith, E. R. (2000). Intergroup emotions: Explaining offensive action tendencies in an intergroup context. fournal of Personality and Social Psychology, 79, 602-616. https://doi.org/10.1037/0022-3514.79.4.602

MacWilliams, M. (2016, January 17). The one weird trait that predicts whether you're a Trump supporter. Politico Magazine, 17. Retrieved from https://www.politico.com/magazine/story/2016/01/donald-trump-2016-authoritarian-213533

Marcus, G. E., Neuman, W. R., \& MacKuen, M. (2000). Affective intelligence and political judgement. Chicago, IL, USA: The University of Chicago Press.

Mason, L. (2013). The rise of uncivil agreement: Issue versus behavioral polarization in the American electorate. The American Behavioral Scientist, 57, 140-159. https://doi.org/10.1177/0002764212463363

Mason, L. (2015). "I disrespectfully agree": The differential effects of partisan sorting on social and issue polarization. American Journal of Political Science, 59(1), 128-145. https://doi.org/10.1111/ajps.12089

Mason, L. (2018). Ideologues without issues: The polarizing consquences of ideological identities. Public Opinion Quarterly, 82, 866-887. https://doi.org/10.1093/poq/nfy005

Merolla, J. L., Ramos, J. M., \& Zechmeister, E. J. (2007). Crisis, charisma, and consequences: Evidence from the 2004 US presidential election. The fournal of Politics, 69(1), 30-42. https://doi.org/10.1111/j.1468-2508.2007.00492.x

Merolla, J. L., \& Zechmeister, E. J. (2009). Democracy at risk: How terrorist threats affect the public. Chicago, IL, USA: University of Chicago Press.

Miller, J. M., \& Krosnick, J. A. (2004). Threat as a motivator of political activism: A field experiment. Political Psychology, 25(4), 507-523. https://doi.org/10.1111/j.1467-9221.2004.00384.x

Mudde, C. (2007). The populist radical Right in Europe. Cambridge, United Kingdom: Cambridge University Press.

Peresman, A., Carroll, R., \& Bäck, H. (2021). Authoritarianism and immigration attitudes in the UK. Political Studies. Advance online publication. https://doi.org/10.1177/00323217211032438

Reiljan, A. (2020). Fear and loating across party lines (also) in Europe: Affective polarization in European party systems. European fournal of Political Research, 59(2), 376-396. https://doi.org/10.1111/1475-6765.12351

Reiljan, A., \& Ryan, A. (2021). Ideological tripolarization, partisan tribalism and institutional trust: The foundations of affective polarization in the Swedish multiparty system. Scandinavian Political Studies, 44(2), 195-219.

https://doi.org/10.1111/1467-9477.12194 
Renström, E. A., Bäck, H., \& Schmeisser, Y. (2020). Vi ogillar olika. Affektiv polarisering bland svenska väljare [We dislike different. Affective polarization among Swedish voters]. In U. Andersson, A. Carlander, \& P. Öhberg (Eds.), Regntunga skyar (pp. 427-443). Gothenburg, Sweden: University of Gothenburg, SOM-institute.

Riek, B. M., Mania, E. W., \& Gaertner, S. L. (2006). Intergroup threat and outgroup attitudes: A meta-analytic review. Personality and Social Psychology Review, 10, 336-353. https://doi.org/10.1207/s15327957pspr1004_4

Rogowski, J. C., \& Sutherland, J. L. (2016). How ideology fuels affective polarization. Political Behavior, 38(2), 485-508. https://doi.org/10.1007/s11109-015-9323-7

Ryan, A., \& Reiljan, A. (2018). Åsikts- och känslomässig polarisering 1985-2014. In D. Karlsson (Ed.), Folkets främsta företrädare (pp. 129-150). Göteborg, Sweden: Göteborgs universitet: Förvaltningshögskolan och Statsvetenskapliga institutionen.

SÄPO [Swedish Security Service]. (2019). Utveckling av den våldsbejakande höger-extremismen [Development of the violent rightwing extremism] Retrieved from https:/www.sakerhetspolisen.se/ovrigt/pressrum/aktuellt/aktuellt/2019-08-22-utveckling-av-den-valdsbejakandehogerextremismen.html

Stanley, B. (2008). The thin ideology of Populism. fournal of Political Ideologies, 13, 95-110. https://doi.org/10.1080/13569310701822289

Stephan, W. G., Ybarra, O., \& Morrison, K. R. (2009). Intergroup threat theory. In T. Nelson (Ed.), Handbook of prejudice. Mahwah, NJ, USA: Lawrence Erlbaum.

Stephan, W. G., Ybarra, O., \& Rios, K. (2015). Intergroup threat theory. In T. D. Nelson (Ed.), Handbook of prejudice, stereotyping, and discrimination (2nd ed., pp. 255-278). Mahwah, NJ, USA: Lawrence Erlbaum Associates.

Tajfel, H. (1978). Differentiation between social groups: Studies in the social psychology of intergroup relations. London, United Kingdom: Academic Press.

Tajfel, H., \& Turner, J. (1979). An integrative theory of intergroup conflict. In W. G. Austin \& S. Worchel (Ed.), The social psychology of intergroup relations (pp. 33-47). Monterey, CA, USA: Brooks Cole.

Tajfel, H., \& Turner, J. C. (1986). An integrative theory of intergroup conflict. In W. G. Austin \& S. Worchel (Eds.), The social psychology of intergroup relations (pp. 33-37). Monterey, CA, USA: Brooks/Cole.

Turner, J. C., \& Reynolds, K. J. (2010). The story of social identity. In T. Postmes \& N. Branscombe (Eds.), Rediscovering social identity: core sources (pp. 13-32). New York, NY, USA: Psychology Press.

Wagner, M. (2021). Affective polarization in multi-party systems. Electoral Studies, 69, Article 102199. https://doi.org/10.1016/j.electstud.2020.102199

Webster, S. W., \& Abramowitz, A. I. (2017). The ideological foundations of affective polarization in the US electorate. American Politics Research, 45(4), 621-647. https://doi.org/10.1177/1532673X17703132 


\section{Appendix}

\section{Study 1}

Table A1 shows the correlations between all variables in Study 1.

\section{Table A1}

Correlations Between All Variables in Study 1

\begin{tabular}{|c|c|c|c|c|c|c|c|c|}
\hline Variable & 1 & 2 & 3 & 4 & 5 & 6 & 7 & 8 \\
\hline 1. Polarization & - & & & & & & & \\
\hline 2. Democracy concern & .05 & - & & & & & & \\
\hline 3. Refugee concern & .01 & $.16^{* * *}$ & - & & & & & \\
\hline 4. Gender & $-.09^{* *}$ & $.12^{* * *}$ & -.02 & - & & & & \\
\hline 5. Age & -.01 & $.13^{* * *}$ & $.12^{* * *}$ & -.01 & - & & & \\
\hline 6. Education & .04 & .01 & $-.17^{* * *}$ & $.08^{* *}$ & $-.24^{* * *}$ & - & & \\
\hline 7. Income & .02 & $-.10^{* * *}$ & $-.11^{* * *}$ & $-.09^{* *}$ & -.24 & $.32^{* * *}$ & - & \\
\hline 8. Left-right & $-.15^{* * *}$ & $-.21^{* * *}$ & $.15^{* * *}$ & $-.07^{*}$ & .01 & $.06^{*}$ & $.17^{* * *}$ & - \\
\hline
\end{tabular}

${ }^{*} p<.05 .{ }^{* *} p<.01 .{ }^{* * *} p<.001$.

To test for differences in polarization between supporters of different parties, a univariate ANOVA with preferred party as independent variable and like-dislike score as dependent variable was performed. Pairwise comparisons using bonferroni post-hoc test was used. The results are presented in Table A2. There was a significant main effect of preferred party, $F(7,1409)=13.51, p<.001, \eta_{\mathrm{p}}^{2}=$ 0.06 .

\section{Table A2}

Means and Standard Deviations for Affective Polarization (Like-Dislike) Divided on Preferred Party Significance Tested Against Other Parties

\begin{tabular}{|c|c|c|c|}
\hline Preferred party & $M(S D)$ & Significantly different from: & Not significantly different from: \\
\hline \multirow[t]{6}{*}{ Left party } & $2.27(1.90)$ & Social democrats ${ }^{* *}$ & Sweden democrats \\
\hline & & Green party*** & \\
\hline & & Center party ${ }^{* * *}$ & \\
\hline & & Liberals $^{* * *}$ & \\
\hline & & Moderats ${ }^{* * *}$ & \\
\hline & & Christian democrats ${ }^{* *}$ & \\
\hline \multirow[t]{4}{*}{ Social democrats } & $4.41(1.98)$ & Left party ${ }^{* *}$ & Green party \\
\hline & & Center party* & Moderates \\
\hline & & Liberals $^{* * *}$ & Christian democrats \\
\hline & & & Sweden democrats \\
\hline \multirow[t]{4}{*}{ Green Party } & $4.04(1.91)$ & Left party ${ }^{* * *}$ & Social democrats \\
\hline & & Liberals $^{* *}$ & Center party \\
\hline & & Sweden democrats ${ }^{* *}$ & Moderates \\
\hline & & & Christian democrats \\
\hline \multirow[t]{4}{*}{ Center Party } & $3.50(1.56)$ & Left party ${ }^{* * *}$ & Green party \\
\hline & & Social democrats* & Liberals \\
\hline & & Sweden democrats ${ }^{* * *}$ & Moderates \\
\hline & & & Christian democrats \\
\hline
\end{tabular}




\begin{tabular}{|c|c|c|c|}
\hline Preferred party & $M(S D)$ & Significantly different from: & Not significantly different from: \\
\hline \multirow[t]{5}{*}{ Liberals } & $3.20(1.56)$ & Left party ${ }^{* * *}$ & Center party \\
\hline & & Social democrats ${ }^{* * *}$ & Christian democrats \\
\hline & & Green party** & \\
\hline & & Moderates ${ }^{* * *}$ & \\
\hline & & Sweden democrats ${ }^{* * *}$ & \\
\hline \multirow[t]{4}{*}{ Moderates } & $4.14(1.50)$ & Left party ${ }^{* * *}$ & Social democrats \\
\hline & & Liberals $^{* * *}$ & Green party \\
\hline & & Sweden democrats ${ }^{* *}$ & Center party \\
\hline & & & Christian democrats \\
\hline \multirow[t]{5}{*}{ Christian democrats } & $3.96(1.73)$ & Left party** & Social democrats \\
\hline & & Sweden democrats ${ }^{*}$ & Green party \\
\hline & & & Center party \\
\hline & & & Liberals \\
\hline & & & Moderates \\
\hline \multirow[t]{5}{*}{ Sweden democrats } & $4.86(2.37)$ & Green party** & Left party \\
\hline & & Center party ${ }^{* * *}$ & Social democrats \\
\hline & & Liberals $* * *$ & \\
\hline & & Moderates $^{* *}$ & \\
\hline & & Christian democrats* & \\
\hline
\end{tabular}

${ }^{*} p<.05 .{ }^{* *} p<.01 .{ }^{* * *} p<.001$.

\section{Study 2}

Table A3 shows the correlations between all variables in Study 2 .

\section{Table A3}

Correlations Between All Variables in Study 2

\begin{tabular}{|c|c|c|c|c|c|c|c|c|c|}
\hline Variable & 1 & 2 & 3 & 4 & 5 & 6 & 7 & 8 & 9 \\
\hline 1. Polarization (traits) & - & & & & & & & & \\
\hline 2. Social distance & $.48^{* * *}$ & - & & & & & & & \\
\hline 3. Extremism concern & .03 & .03 & - & & & & & & \\
\hline 4. Refugee concern & $.08^{* *}$ & .04 & $-.10^{* * *}$ & - & & & & & \\
\hline 5. Gender & $-.07^{* *}$ & -.04 & $.18^{* * *}$ & -.00 & - & & & & \\
\hline 6. Age & -.01 & -.06 & $.07^{* *}$ & $.15^{* * *}$ & .09 & - & & & \\
\hline 7. Education & -.05 & -.01 & -.01 & -.01 & -.02 & .12 & - & & \\
\hline 8. Income & -.02 & .00 & .00 & .02 & .04 & -.04 & $.43^{* * *}$ & - & \\
\hline 9. Left-right & .02 & .04 & $-.21^{* * *}$ & $.30^{* * *}$ & $-.09^{* *}$ & -.03 & -.01 & -.02 & - \\
\hline
\end{tabular}

${ }^{*} p<.05 .{ }^{* *} p<.01 .{ }^{* * *} p<.001$.

To test for differences in polarization between supporters of different parties, two univariate ANOVAs with preferred party as independent variable and the polarization score (trait-ratings and social distance) as dependent variable was performed. Pairwise comparisons using bonferroni post-hoc test was used. The results are presented in Table A4 and Table A5. For both dependent variables there were significant main effects of preferred party; trait-ratings: $F(7,1304)=12.42, p<.001 \eta_{\mathrm{p}}^{2}=0.06$, and social distance: $F(7,1268)=4.60, p<.001, \eta_{\mathrm{p}}^{2}=0.03$. 


\section{Table A4}

Means and Standard Deviations for Affective Polarization (Trait-Ratings) Divided on Preferred Party Significance Tested Against Other Parties

\begin{tabular}{|c|c|c|c|}
\hline Preferred party & $M(S D)$ & Significantly different from: & Not significantly different from: \\
\hline \multirow[t]{5}{*}{ Left party } & $1.79(1.21)$ & Social democrats ${ }^{* * *}$ & Liberals \\
\hline & & Green party ${ }^{* *}$ & Sweden democrats \\
\hline & & Center party*** & \\
\hline & & Moderates ${ }^{* * *}$ & \\
\hline & & Christian democrats* & \\
\hline \multirow[t]{5}{*}{ Social democrats } & $1.05(1.02)$ & Left party ${ }^{* * *}$ & Green party \\
\hline & & Sweden democrats ${ }^{* * *}$ & Center party \\
\hline & & & Liberals \\
\hline & & & Moderates \\
\hline & & & Christian democrats \\
\hline \multirow[t]{5}{*}{ Green party } & $1.18(0.83)$ & Left party ${ }^{* *}$ & Social democrats \\
\hline & & Sweden democrats ${ }^{* *}$ & Center party \\
\hline & & & Liberals \\
\hline & & & Moderates \\
\hline & & & Christian democrats \\
\hline \multirow[t]{5}{*}{ Center party } & $1.05(0.92)$ & Left party ${ }^{* * *}$ & Social democrats \\
\hline & & Sweden democrats ${ }^{* * *}$ & Green party \\
\hline & & & Liberals \\
\hline & & & Moderates \\
\hline & & & Christian democrats \\
\hline \multirow[t]{7}{*}{ Liberals } & $1.32(1.13)$ & & Left party \\
\hline & & & Social democrats \\
\hline & & & Green party \\
\hline & & & Center party \\
\hline & & & Moderates \\
\hline & & & Christian democrats \\
\hline & & & Sweden democrats \\
\hline \multirow[t]{5}{*}{ Moderates } & $1.11(1.04)$ & Left party ${ }^{* * *}$ & Social democrats \\
\hline & & Sweden democrats ${ }^{* * *}$ & Green party \\
\hline & & & Center party \\
\hline & & & Liberals \\
\hline & & & Christian democrats \\
\hline \multirow[t]{5}{*}{ Christian democrats } & $1.26(1.12)$ & Left party* & Social democrats \\
\hline & & Sweden democrats & Green party \\
\hline & & & Center party \\
\hline & & & Liberals \\
\hline & & & Moderates \\
\hline \multirow[t]{5}{*}{ Sweden democrats } & $1.79(1.68)$ & Social democrats ${ }^{* * *}$ & Liberals \\
\hline & & Green party ${ }^{* *}$ & \\
\hline & & Center party ${ }^{* * *}$ & \\
\hline & & Moderates ${ }^{* * *}$ & \\
\hline & & Christian democrats ${ }^{* *}$ & \\
\hline
\end{tabular}

${ }^{*} p<.05 .{ }^{* *} p<.01 .{ }^{* * *} p<.001$. 


\section{Table A5}

Means and Standard Deviations for Affective Polarization (Social Distance) Divided on Preferred Party Significance Tested Against Other Parties

\section{Preferred party}

Left party

Green party

Center party

Liberals

Moderates

\section{$M(S D)$}

$1.22(1.16)$

$0.74(1.03)$

$0.70(0.69)$

$0.78(0.87)$

$0.94(1.02)$

$0.86(1.12)$
Significantly different from:

Social democrats**

Left party**

Sweden democrats**

Sweden democrats*
Not significantly different from:

Green party

Center party

Liberals

Moderates

Christian democrats

Sweden democrats

Green party

Center party

Liberals

Moderates

Christian democrats

Left party

Social democrats

Center party

Liberals

Moderates

Christian democrats

Sweden democrats

Left party

Social democrats

Green party

Liberals

Moderates

Christian democrats

Left party

Social democrats

Green party

Center party

Moderates

Christian democrats

Sweden democrats

Left party

Social democrats

Green party

Center party

Liberals

Christian democrats

Sweden democrats 


\section{Preferred party}

Christian democrats $M(S D)$ $0.79(1.13)$

$1.17(1.60)$

Sweden democrats

Center party*
Significantly different from:

Not significantly different from:

Left party

Social democrats

Green party

Center party

Moderates

Liberals

Sweden democrats

Left party

Green party

Moderates

Liberals

Christian democrats

Sweden democrats

${ }^{*} p<.05 .{ }^{* *} p<.01 .{ }^{* * *} p<.001$. 